\title{
Closer Co-operation, a new instrument for European Environmental Policy?
}

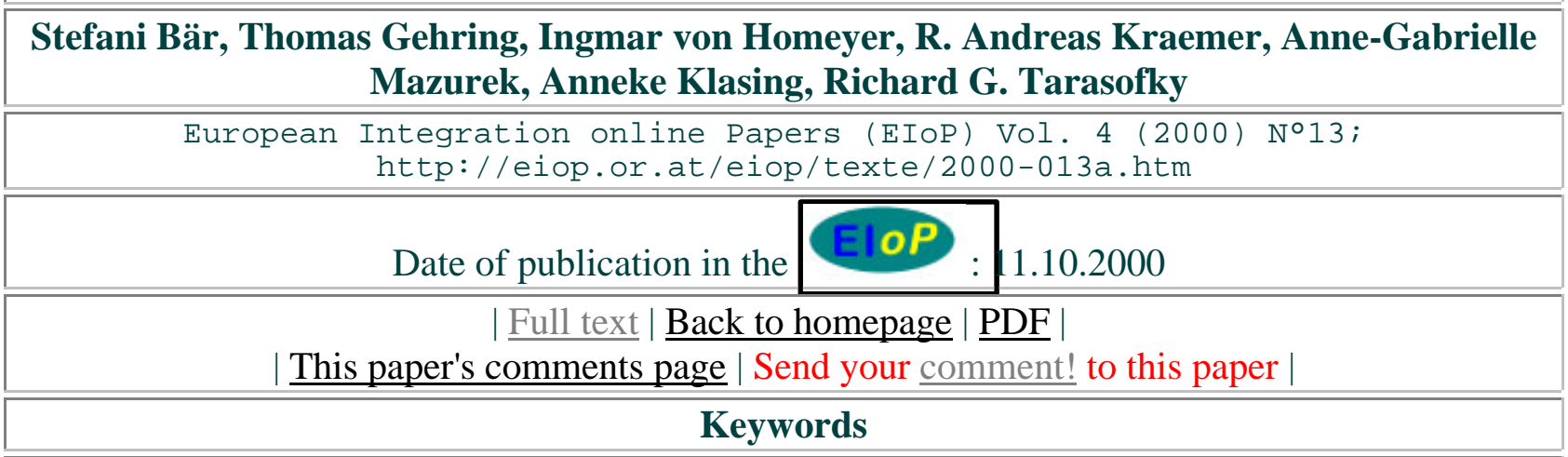

Amsterdam Treaty, closer cooperation, environmental policy, founding Treaties, harmonisation, integration theory, intergovernmental conferences, legislative procedure, majority voting, qualified majority, subsidiarity, treaty reform, unanimity, law

\begin{tabular}{|l|}
\hline \multicolumn{1}{|c|}{ Abstract } \\
\hline The Amsterdam Treaty has created a new instrument for European integration: Closer \\
Co-operation. This allows a majority of Member States, i.e. currently eight countries, to take joint \\
action and use the institutions and procedures of the European Union for this purpose, thereby \\
further developing European integration in a flexible way. This right is tied to several conditions \\
that largely ensure that Closer Co-operation will not significantly affect the homogeneity of the \\
legal area and will not lead to a sustained split of the Union. \\
The following concise analysis is based on the more detailed study "Verstärkte Zusammenarbeit im \\
Umweltbereich - Möglichkeiten der Anwendung der in Titel VII TEU festgelegten Bestimmungen \\
für Flexibilität im Umweltbereich" commissioned by the Austrian Federal Ministry of \\
Environment, Youth and Family Affairs. It examines the legal requirements and political \\
framework conditions which are necessary for applying the new procedure of Closer Co-operation \\
to the Community's environmental policy. Furthermore, an analysis was performed to see in how \\
far Closer Co-operation could generate a new dynamism in the development of European \\
environmental policy and which long-term effects are to be expected on the integration process. \\
The prerequisites laid down in the Treaty for the implementation of Closer Co-operation require \\
further interpretation in some cases, but this does not preclude the instrument's practical \\
applicability in European environmental policy.
\end{tabular}

\section{Kurzfassung}

Die Verstärkte Zusammenarbeit wurde durch den Amsterdamer Vertrag in die Europäischen Verträge eingefügt. Danach kann eine Mehrheit der Mitgliedstaaten (derzeit acht Staaten) die Institutionen und Verfahren der Europäischen Union nutzen, um gemeinsam Maßnahmen zur flexiblen Weiterentwicklung der europäischen Integration zu ergreifen. Dieses Recht setzt die Erfüllung einer Reihe von Bedingungen voraus, die u.a. sicherstellen sollen, dass der einheitliche Rechtsraum durch eine Verstärkte Zusammenarbeit nicht gefährdet wird.

Der vorliegende Artikel basiert auf der Studie "Verstärkte Zusammenarbeit im Umweltbereich Möglichkeiten der Anwendung der in Titel VII EUV festgelegten Bestimmungen für Flexibilität im Umweltbereich", die vom österreichischen Bundesministerium für Umwelt, Jugend und Familie in Auftrag gegeben wurde. Hierin wird untersucht, unter welchen rechtlichen Voraussetzungen und politischen Rahmenbedingungen das neu geschaffene Verfahren der Verstärkten Zusammenarbeit der Entwicklung der Europäischen Umweltpolitik eine neue Dynamik verleihen kann und welche langfristige Auswirkungen auf den Integrationsprozess zu erwarten sind.

Aus der Untersuchung ergibt sich, dass die im Vertrag festgelegten Voraussetzungen für die Durchführung einer Verstärkten Zusammenarbeit in einigen Fällen zwar auslegungsbedürftig sind, doch dass eine Anwendbarkeit des Instruments in der Praxis der europäischen Umweltpolitik nicht ausgeschlossen ist. 
The authors

All authors work with Ecologic, Gesellschaft für Internationale und Europäische Umweltforschung, a think tank focussing on international and European environmental research based in Berlin; email: baer@ecologic.de or kraemer@ecologic.de 
Closer Co-operation, a new instrument for European Environmental Policy?

Stefani Bär, Thomas Gehring, Ingmar von Homeyer, R. Andreas Kraemer, Anne-Gabrielle Mazurek, Anneke Klasing, Richard G. Tarasofky

European Integration online Papers (EIoP) Vol. 4 (2000) $\mathrm{N}^{\circ}$ 13; http://eiop.or.at/eiop/texte/2000-013a.htm

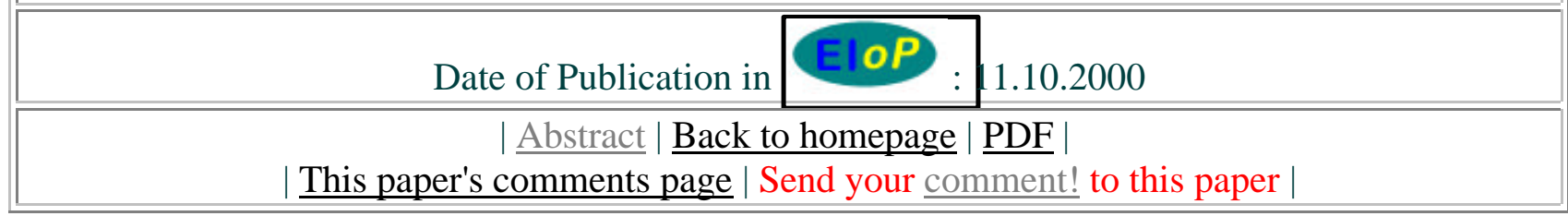

\section{Contents:}

- 1 . Introduction and Background

- 2. Legal Prerequisites of Closer Co-operation

- 2.1 Structure of Closer Co-operation in the Treaties

- 2.2 Failure of the Procedure

- 2.3 Request of the Member States

- 2.4 Proposal by the Commission and Observance of the Requirements

- 2.4.1 Conditions to protect the European Union

- 2.4.2 Regulations on the Protection of Minorities

- 2.4.3 Prohibition of Discrimination and Distortion of Competition

- 2.5 Consultation of the European Parliament

- 2.6 Decisions in the Council

- 2.7 Later Participation of Member States

- 2.8 Intermediate Result

- 3. Application Potential in European Environmental Policy

- 3.1 Closer Co-operation and Unanimity

- 3.2 Product-related Regulations

- 3.3 Process Regulations

- 3.4 Other Regulations

- 3.5 Implementation of International Agreements

- 3.6 Closer Co-operation and Eastern Enlargement

3.6.1 Problems of Enlargement

- 3.6.2 The Influence of Institutional Reforms

- 3.6.3 Differences between the Candidate Countries

- 3.6.4 Enlargement and Existing Cases of Closer Co-operation

- 4. Impact on the Integration Process

$\circ 4.1$,Threatening Effect" of Closer Co-operation

- 4.2 Pull Effect of Closer Co-operation

- 4.3 Interests of the European Institutions and the „Ins“"

- 5. Conclusions

- $\underline{\text { References }}$

\section{Introduction and Background ${ }^{\boldsymbol{}}$}

The following analysis is based on the study „Verstärkte Zusammenarbeit im Umweltbereich Möglichkeiten der Anwendung der in Titel VII TEU festgelegten Bestimmungen für Flexibilität im 
Umweltbereich" commissioned by the Austrian Federal Ministry of Environment, Youth and Family Affairs in September 1999.(1)

The Amsterdam Treaty has created a new instrument for European integration: Closer Co-operation. This allows a majority of Member States, i.e. currently eight countries, to take joint action and use the institutions and procedures of the European Union for this purpose, thereby further developing European integration in a flexible way. This right is tied to several conditions that largely ensure that Closer Co-operation will not significantly affect the homogeneity of the legal area and will not lead to a sustained split of the Union.

The amendments included in the Amsterdam Treaty with regard to Closer Co-operation are another step towards a more differentiated integration process, a development that started already in the 1970's. More than any other field of European policy, the discussion of differentiation within the Community is characterised by a variety of concepts and terms related to different strategies and objectives.(2) A few examples may serve to illustrate the wide spectrum of the discussion: „variable-geometry Europe“, „,multi-speed Europe“ or the concept of „,core Europe“.(므) But also the French „Europe à la carte“ or the English „,multi-tier Europe“( $\underline{4})$ played a major role in the discussion.(므) There is no agreed understanding of these terms and the variety of interpretations contribute a lot to the lack of clarity of the thematic debate.

European environmental policy stands out for its flexibility which is due to the fact that it has always had to consider different requirements in terms of nature areas and substance. This necessity of flexible responses to different conditions is met by the establishment of permanent exemptions or temporary transition periods within the framework of the EC Treaty or in individual secondary legislation (directives or regulations). Under certain (strict) conditions, European law, for example, permits that environmentally advanced Member States adopt more stringent product( $\underline{6})$ or process standards() than achieved at a Community level. Individual measures of the Community, such as the Large Combustion Plants Directive( $\underline{8})$ or the Auto-Oil Programme( $\underline{9})$, include transition periods for individual countries or other provisions that cater to different needs. Hence, the flexible regulation of environmental policy objectives is nothing new at the European level.

The following chapters analyse the legal prerequisites of Closer Co-operation and then identify fields where it can be applied in European environmental policy. This is followed by a brief assessment of the longer-term impact of the application of Closer Co-operation on the integration process of the Community.

\section{Legal Prerequisites of Closer Co-operation}

Numerous requirements that finally have been introduced into the Treaties reflect the concerns expressed by some Member States within the framework of the Intergovernmental Conference that resulted in the adoption of the Amsterdam Treaty.(10) The fears of a permanent split of the Community and a division of the Member States into two classes were in contrast to the demand for more integration. The functioning of the Union and the possibility to achieve progress was not to be impeded by temporary difficulties of a partner to keep pace with the other Member States. $(\underline{11})$

\subsection{Structure of Closer Co-operation in the Treaties}

The provisions on Closer Co-operation, which were introduced both into the EU Treaty and into the 
EC Treaty by the Amsterdam Treaty, comprise so-called general clauses and special authorisation provisions. The general clauses are laid down in Title VII of the EU Treaty and are horizontal provisions for all the three pillars of the European Union. For the first (EC Treaty( 12$)$, Euratom, ECSC(13), EMU(14)) and third pillars (police and justice Co-operation in criminal matters), special authorisation clauses are defined. The conditions contained therein for the implementation of Closer Co-operation are to be observed as cumulative stipulations in addition to the general clauses. In the field of foreign and security policy, the second pillar, Closer Co-operation is not envisaged within the framework of the European Union. The concept of „,constructive abstention“ mentioned in that field is not an applied case of Closer Co-operation under the terms of Title VII TEU.(모)

The following analysis of the legal prerequisites is limited to the EC Treaty that serves as a basis for the adoption of the European environmental policy.

The procedure for establishing Closer Co-operation can be divided into three phases. The procedure actually authorising the Member States to establish Closer Co-operation is always preceded by a „,normal" legislation procedure. Only if this procedure fails, the process laid down in Articles 43 and 44 TEU and Article 11 TEC may be initiated to establish Closer Co-operation. In this context, a basic differentiation has to be made between the authorisation procedure and the implementation decisions. Within the framework of the former, the majority of the Member States is granted the basic authorisation for engaging in Closer Co-operation. Following this authorisation, implementation decisions are taken in accordance with the procedure laid down in the EC Treaty, however, with the difference that only the Member States participating in Closer Co-operation (the „Ins“) vote on the implementation decision.

\subsection{Failure of the Procedure}

An initiative in the field of Closer Co-operation requires that a legislation procedure fails. Closer Co-operation can only be used, ,as a last resort, where the objectives of the said Treaties could not be attained by applying the relevant procedures laid down therein" $(\underline{16})$. This provision reflects the intention of the Member States to clearly make Closer Co-operation an exception. This was to clarify that the new instrument only served as ultima ratio( $\underline{17})$, as an ,emergency concept“( $\underline{18})$.

However, this does not yet clearly define a point in time when Closer Co-operation can be initiated. According to Janning, the threshold to ultima ratio is crossed when, for a prolonged period of time, the Council cannot reach agreement on matters contributing to the achievement of Treaty objectives.(19) Since the European Commission initiates Community measures, the discussions of the Council are, as a rule, based on a proposal submitted by the Commission. The crucial question is whether the withdrawal of a proposal by the Commission also constitutes a „failure“ or whether a formal decision of the Council is required to ,evidence that a project failed“. Moreover, it is not clear how much time needs to have gone by in the course of a legislation process before the procedure can be assumed to have failed and who decides on the existence of a failure.

The need to clarify these issues, however, does not preclude the application of Closer Co-operation in European environmental policy per se. After all, Member States desiring Closer Co-operation can request the Council's President to take a vote in the Council at any time. (20) By such a vote, a procedure can be declared to have failed.

In the field of European environmental policy, there are three procedural situations in which a „failure" may occur. 
a. Unanimity cannot be achieved in the Council.(21)

b. A qualified majority cannot be achieved in the Council.(22)

c. A legislative proposal fails due to rejection by the European Parliament.

With regard to the first case, it was relatively difficult in the past to achieve agreement in the fields that required unanimity in the Council for adopting environmental measures. The increasing number of Member States will make it even more difficult to reach unanimity at a European level in the future. $(\underline{23})$ Thus, the instrument of Closer Co-operation is basically suitable in this case. But also failure to achieve a qualified majority is a case conceivable in European environmental policy that may call for Closer Co-operation. It is possible that countries are not ready to commit to a Community action, but do not have any objections to a Closer Co-operation by the other Member States. The case that Closer Co-operation is initiated following the rejection of a proposal by the European Parliament seems to be rather unlikely.

At a European level, around 100 legislation procedures are pending in the environmental field most of them already for more than ten years without a directive or regulation having been adopted. This illustrates the potential field of practical application for Closer Co-operation.

\subsection{Request of the Member States}

The Member States wishing to establish Closer Co-operation can address a request to the Commission which may present a proposal to that effect to the Council.(24) This requires the majority of the Member States, i.e. eight Member States in the current situation of EU 15.(25) If the Commission decides against submitting a proposal, it has to inform the Member States concerned of this decision and state its reasons. On the one hand, the majority requirement is to ensure that ,rivalling“ groups are not formed among the Member States in a field of regulation.(26) On the other hand, this precludes the formation of a small vanguard along the lines of the much discussed ,core Europe“" or „Europe à la carte“.

An open issue concerns the criteria to be used for deciding which Member States are to participate in Closer Co-operation and who may take this decision.(27) This is problematic in a case when a Member State participated in submitting the request for Closer Co-operation, but is not considered capable of meeting the requirements within the framework of Closer Co-operation. If not resolved otherwise, such disputes will have to be submitted to the European Court of Justice.

In practice, the majority of Member States will vary from case to case, depending on the topic under discussion. A core group of environmental leaders who will co-operate closer in numerous cases for the entire environmental field can not be identified in the light of previous experience.

\subsection{Proposal by the Commission and Observance of the Requirements}

As mentioned above, Closer Co-operation is initiated by a proposal of the Commission. In its function as the „Guardian of the Treaties“, the Commission is obliged to examine whether the requirements of Closer Co-operation laid down in the Treaties are met.

Both the EU Treaty and the EC Treaty contain a list of conditions to be fulfilled if Closer Co-operation is to be applied in the field of European environmental policy.(28) This is to ensure that the effects on the institutional framework of the Community that may be caused by Closer 
Co-operation do not exceed a certain level.(29)

The conditions of the EU and EC Treaty can be grouped into two categories. They are to protect, on the one hand, the European Union as a whole and, on the other hand, the minority of the Member States, the „outs“. In the following, we concentrate on the former conditions.

\subsubsection{Conditions to protect the European Union}

Closer Co-operation is permitted if it, is aimed at furthering the objectives of the Union and at protecting and serving its interests". $(\underline{30})$ The reference to the objectives of the Union clarifies that Closer Co-operation can only be used as a means to achieve faster progress by some Member States. This is to explicitly preclude a step back, for example, towards lower standards.(31) Moreover, this provision highlights that the aim is not to split the Union by a series of individual decisions, but rather to strengthen it by the exemplary progress by some countries with regard to the objectives and interests of the Union. $(\underline{32})$

Another requirement is the provision that Closer Co-operation ,respects the principles of the said Treaties and the single institutional framework of the Union".(포 $)$ The renewed emphasis( $\underline{34})$ on the observance of the principles and the institutional framework of the Union makes clear that Closer Co-operation must not create new institutional structures nor result in amendments to the Treaties. This is further underlined by the provisions of Article 11 (1) (d) TEC which states that Closer Co-operation ,remains within the limits of the powers conferred upon the Community by this Treaty“. Moreover, Closer Co-operation ,,does not concern areas which fall within the exclusive competence of the Community“.(모)

The provisions adopted within the framework of Closer Co-operation must ,... not affect the 'acquis communautaire' and the measures adopted under the other provisions of the said Treaties".(하) In addition to primary law, the ,acquis communautaire“ also includes the entire secondary law adopted by the institutions of the Union.(37) The obligation of not affecting the ,acquis communautaire" is to ensure that it is maintained as a homogenous unit.(표)

For the adoption of environmental measures within the framework of Closer Co-operation in the non-harmonised field, i.e. where no Community legislation exists as yet, this means that primary law must not be violated.(39) In the environmental field, Articles $28 \mathrm{ff}$. TEC are of special importance, because they prohibit import restrictions and measures having the same effect. Therefore, the prerequisites applying to Closer Co-operation in the non-harmonised field are not stricter than those applicable to national measures. Thus, the Member States may form a group for Closer Co-operation under the same conditions applicable to national measures. Provided that the other conditions are met, the actions conceivable particularly include:

- the adoption of directives or regulations;

- the regulation of an entire area not yet harmonised at the European level.

In the fields in which the Community already adopted environmental regulations, it is to be borne in mind that the above provision prevents that some Member States form a group to lower the standards defined by the ,acquis communautaire“. However, the „collective raising“" of the Community's protective level is permitted. Here, parallels to the „,national solo“ under Article 95 (4) and (5) and Article 176 TEC become obvious. In contrast to the „national solo“, which presupposes the successful adoption of Community provisions, the „collective solo“ requires that precisely such a 
measure „failed“.(느) Subject to compliance with the other provisions, it is basically admissible to:

- render an existing directive more stringent;

- use a new instrument to achieve an objective defined in a harmonisation measure.

As a result, we can state that the requirement of not affecting the ,acquis communautaire“ basically allows for Closer Co-operation in cases in which national action is permitted as well. Probably, the result of this condition will be that Closer Co-operation will mainly, but not exclusively, take place in areas in which few or no Community regulations have been adopted so far.(1ㅡ)

In the EC Treaty, the requirement of a homogenous legal area is further specified by stating that Closer Co-operation is only possible if it ,does not affect Community policies, actions or programmes ". (42) Hence, Closer Co-operation must not impede the achievement of Community objectives that have not (yet) been dealt with within the framework of legislation, but in programmes, action plans or other measures.(43) This means that Closer Co-operation must not act contrary to the measures envisaged, for example, in the current Environmental Action Programme. At any rate, these measures cannot be anticipated, because Closer Co-operation is conditional on the previous failure of a general procedure. According to Epiney, the prerequisites of this provision could already be met if the measure to be taken within the framework of Closer Co-operation pursues a concept different from the one defined in a Community programme.(44) This would, however, require that the concept of the environmental action programmes was defined in greater detail than usually is the case today.

The concern for the maintenance of a homogenous legal area was taken into consideration by the said provision to very large extent. Divergence can develop if Closer Co-operation is established in a field already harmonised, whereby safeguards higher than the existing protective level are defined. This, however, does not apply in non-harmonised areas. Here, there usually are already many different national regulations whose number can be reduced by joint efforts in Closer Co-operation. It can contribute to replacing many different national acts on the same subject by uniform regulations, at least for the participating countries. Thus, the principle of legislative homogeneity is even favoured, at least in these cases.

\subsubsection{Regulations on the Protection of Minorities}

The provisions for protecting the „outs" include the examination of compliance with the prerequisites by the Commission since Closer Co-operation must not ,affect the competences, rights, obligations and interests of those Member States which do not participate therein" $(\underline{45})$ and is,,open to all Member States and allows them to become parties to the Co-operation at any time, provided that they comply with the basic decision and with the decisions taken within that framework".(46) This condition, also known as the ,principle of openness"( $\underline{47})$, reflects the intention of the signatories not to create a permanent core Europe or „Europe à la carte“", but to allow only a temporary lead by providing the opportunity to catch up with the „leaders“" at a later date.

Similar to the conditions for accession to the European Union, later participation in a sub-field of Closer Co-operation requires that a Member State wishing to participate accepts the basic decision resulting from the relevant authorisation as well as the decisions taken by the „ins“ in the course of their Co-operation. These decisions, so to speak, form the ,acquis“ of the Closer Co-operation in question. The new participating Member State is not able to influence the agreements already achieved and can only participate in forthcoming decisions. The principle of openness of Closer Co-operation, however, means that the participating Member States have to shape Closer 
Co-operation in such a way that the participation of further Member States is not made permanently impossible in practice. $(\underline{48})$

\subsubsection{Prohibition of Discrimination and Distortion of Competition}

A high barrier to the practical application of Closer Co-operation could, however, be the prohibition of discrimination.(49) This means that Closer Co-operation must not ,constitute a discrimination or a restriction of trade between Member States and does not distort the conditions of competition between the latter". $(\underline{50)}$

The discrimination ban, which also forms the basis of other norms of the Treaty (Articles 28, 95 and 176 TEC), is to meet the concerns of Member States fearing that Closer Co-operation could be abused as an instrument of covert protectionism due to economic interests.

Court rulings indicate that the prohibition of discrimination among the Member States is a more specific rendering of the principle of proportionality.(51) Inadmissible discrimination exists if a sovereign entity, in its jurisdiction, treats equivalent situations in a dissimilar way or dissimilar situations in an equivalent way.(52) Applied to the movement of goods, this means, for example, that domestic manufacturers of goods and products must not be given preferential treatment over their foreign competitors without technical reasons by diverging national special regulations. (53) Within the framework of Closer Co-operation, such a discrimination may occur if stricter product standards are introduced in the territory of the ,ins“ and products manufactured in the „outs“ that do not comply with these standards must not be sold in the ,ins“. But unequal treatment per se is not prohibited. Using the justifications for discrimination within the framework of Article 28 or Article 95 TEC, we can assume that unequal treatment is permitted for reasons of environmental protection provided that it is proportionate to the restriction of trade.(54) According to the generally accepted definition of proportionality in terms of administrative and constitutional law, an action is proportionate if it is suitable for pursuing the objective envisaged, necessary and reasonable.(5)

With regard to the prohibition of discrimination and the restriction of trade caused by measures of Closer Co-operation, we can, thus, state the following: It mainly concerns regulations on products, but unequal treatment of products manufactured by the „ins“ and „outs“ may be justified for environmental reasons. The admissibility of a measure to be taken within the framework of Closer Co-operation, however, has to be examined on a case-by-case basis.

Furthermore, it is also of importance for the application of Closer Co-operation in the field of environmental policy that the measures must not distort the conditions of competition between the Member States. $(\underline{56})$

The ban on distortions of competition is another qualification of Article 81 TEC that states that any „prevention, restriction or distortion of competition“ is prohibited. Accordingly, competition is impeded if there is an objectively intensive and sustained negative effect on competition within the common market.(57) Therefore, it cannot be true that competition is already distorted if environmental measures raise the production costs for an industry. Such an interpretation of the ban on distortions of competition would preclude any measures that affect the economic activities of several Member States in any way and thereby impact the competition conditions. As a result, the application of the instrument of Closer Co-operation would be utterly impossible. But such consequences can by no means be intended given the system and orientation of Article 11 (1) TEC. This is also evidenced by the fact that such an interpretation would make Article 43 TEU, newly 
introduced for the field of the first pillar, obsolete. $(\underline{58})$ With a view to the comparable provisions of Articles $28 \mathrm{ff}$. and $35 \mathrm{TEC}$, it is to be assumed that the principle of proportionality also applies to Article 11 (1) (e) TEC. Hence, the distortion of competition has to be weighed against the provisions required for environmental protection. An interpretation along these lines would mean that only national regulations resulting in an inproportionate distortion of competition were not permitted.

As an intermediate result, we can state that the legal requirements of Closer Co-operation according to Article 43 TEU and Article 11 TEC do not preclude its applicability in the environmental field. In individual cases, the admissibility of measures will mainly depend on the assessment of their proportionality by the European Commission.

\subsection{Consultation of the European Parliament}

After the European Commission has examined whether the requirements are met, European Parliament is consulted on the proposed Closer Co-operation.(59) However, there is no obligation to take into consideration the results of the consultation. Thus, the process establishing Closer Co-operation is not subject to the democratic supervision of the Parliament, which it also criticises.(60) The weak position of the Parliament in the authorisation procedure is in stark contrast to its power within the framework of the implementation decisions, which have to be adopted in line with the usual legislation procedures, i.e. the co-decision procedure in most cases in the environmental field. With a view to the fact that the Council has to rely on the Co-operation and agreement of the Parliament within the framework of the implementation decisions, the Parliament should be involved in the negotiations at an early stage in order to ensure the successful implementation of Closer Co-operation. This could be done, for example, in consultation procedures, which are also common in other Community procedures. They ensure that the required majority will subsequently be found for the implementation of the Co-operation planned. Its position in the implementation procedure allows the Parliament to exert a certain influence also in the authorisation procedure.

\subsection{Decisions in the Council}

The decision to establish Closer Co-operation has to be taken by qualified majority in the Council. In the current situation of „EU 15“, this requires at least 62 votes.(1) Closer Co-operation, however, cannot take place against the express will of a Member State. If a member of the Council states that it opposes the granting of an authorisation for ,important and stated reasons of national policy“, a vote will not be taken.(62) In such a case, the Council may, however, request that the issue is referred to the Council meeting in the composition of the heads of state or government for decision by unanimity. The referral to the higher level essentially raises the odds of achieving a compromise within the framework of ,package solutions“.

An open question is who will decide whether there actually is an „,important reason of national policy“"(ㅎ3) Current opinion holds that the reasons stated are only subject to examination by the Court to a limited extent.(64) According to Hall, the statement of the important national reasons in the Council does not constitute an ,act of the Council“" under the terms of Article 230 TEC that could be examined for legitimacy by the European Court of Justice.(다) The Court can only check in terms of procedural law whether the Member State in question fulfilled its duty to state the important reasons of national policy.(66) In political practice, however, it is to be borne in mind that the „veto" might be „bought“ from the blocking Member State, in particular if it does not participate in Closer Co-operation due to a lack of interest or will, but cannot do so for financial or other reasons. 
The practical use of the veto by the Member States will, however, decisively shape the importance of the instrument of Closer Co-operation in the future of the European Union.(무)

\subsection{Later Participation of Member States}

On principle, the states initially not involved are entitled to join the „leaders“ at any time. Article 11 (3) TEC provides a specific procedure to this effect. If a Member State wishes to become a party to an existing Closer Co-operation, it informs the Council and the Commission. Within three months, the Commission submits its opinion to the Council. Within four months, the Commission decides on the request and on any additional arrangements required. This provision is complemented by Article 43 (1) (g) TEU which states that the new participating countries have to comply with the basic decision and the implementation decisions already taken. Consequently, when deciding on the request, the Commission only has to (or may) examine whether the Member State requesting to become a party to the Co-operation meets these requirements and whether any specific transition arrangements are required. Since the Commission is interested in the re-establishment of the homogeneity of the legal area, which can be guaranteed by the involvement of as many additional countries as possible, we can assume that the Commission will basically support participation.

\subsection{Intermediate Result}

The application of Closer Co-operation is possible in the practice of European environmental policy. Even today, the new instrument is more than a ,structural principle of the future".(요 $)$ However, it still needs to be complemented with regard to objectives and mechanisms. The utilisation of the provision by the actors involved will decisively shape the extent of the room for manoeuvre for the individual Member States and will show whether the new instrument develops into a central instrument of integration. National governments, individual politicians and urgent items on the European agenda will determine whether groups of Member States can be formed that meet the formal requirements of Closer Co-operation and, at the same time, are able to resolve the conflicting interests of potentially not participating Member States in such a way that blocking attitudes do not result thereof. As in other legislation procedures, the European Commission will play a major role in decisions on the actual application of Closer Co-operation in the first pillar. Above all, its position allows the Commission to interpret the provisions, which are not defined unambiguously, in a more restrictive or wider way and, thus, to set the standards for the utilisation of the new instrument. The final interpretation of cases of doubt by the ECJ is to be expected only in several years. Up to that time, points needing clarification (e.g. the questions of who decides according to which criteria whether a ,standard“" procedure to adopt a Community measure failed and who has the capabilities required for participating in Closer Co-operation) can already be dealt with within the framework of the next intergovernmental conference.

The application of Closer Co-operation to Council resolutions and conclusions is impossible according to the current state of the discussion. These types of informal and non-binding action of the Council are not explicitly mentioned neither in the EC Treaty nor in the Council's Rules of Procedure, but are part of the standing practice of the Council. Article 43 (2) TEU and Article 44 (1) TEU, however, expressly speak of ,,acts and decisions“. Another argument against the application of Closer Co-operation to Council conclusions is the fact that Article 43 (1) TEU stresses that the Member States wishing to establish Closer Co-operation can make use of the institutions, procedures and mechanisms laid down by the EU Treaty and the EC Treaty. Consequently, Closer Co-operation constitutes a special solution for the legal basis, legislation procedures, etc., defined in the Treaties. 
Hence, Closer Co-operation must be based on the foundations provided by the Treaty. But, as already mentioned above, these are precisely not identified in the Treaties.

Though the new instrument was primarily developed with a view to entire policies (e.g. Schengen, social policy, Economic and Monetary Union), its application to individual acts of secondary law is not precluded. In fact, it will be above all secondary law where potential cases of application will arise, thus resulting in a wide application field in practice.

\section{Application Potential in European Environmental Policy}

As outlined above, the establishment and implementation of Closer Co-operation in environmental policy practice is tied to a series of requirements. Therefore, the potential application, which is to be discussed below, always has to meet these conditions. The most important ones can be summarised as follows:

- Presence of an authorisation basis in the EC Treaty;

- Failure of a procedure laid down in the EC Treaty;

- Request by the majority of Member States;

- Qualified majority in the Council in favour of the authorisation decision;

- No adverse effects on primary and secondary law;

- No discrimination or restrictions of trade or distortion of the conditions for competition.

\subsection{Closer Co-operation and Unanimity}

Under certain conditions, the new instrument of Closer Co-operation may lead to an easing of the unanimity requirement for certain environmental measures. In particular, in the environmental field, central legal bases( $\underline{69})$ are still subject to unanimity. This mainly includes Article 175 (2) TEC which stipulates that unanimity is required in the Council for the following fields:

- provisions primarily of a fiscal nature;

- town and country planning, land use,(0) (quantitative) management of water resources;

- Choice between different energy sources and the general structure of energy supply.

The increasing number of Member States will make the achievement of unanimity even more difficult at a European level in the future. Based on the awareness of this problem, the agenda of the Intergovernmental Conference of 1996 already included the extension of the co-decision procedure with qualified majority voting in the Council. The Amsterdam amendments to the Treaty were, however, only partly successful in this respect. In particular, measures falling under Article 175 (2) TEC still have to be adopted by unanimity. Interestingly enough, the introduction of the instrument of Closer Co-operation into the Treaties of the Community was seriously considered in the discussions of the Intergovernmental Conference only when it became obvious that the far-reaching elimination of the unanimity principle would not be achieved.

The establishment of Closer Co-operation only requires a qualified majority in the Council. If unanimity cannot be achieved to adopt a measure at the Community level, but if a qualified majority is possible, at least eight Member States can join forces to initiate Closer Co-operation. After the adoption of the authorisation decision, however, the countries participating in Closer Co-operation have to unanimously agree on the implementation decisions. The requirement of unanimity is thus 
transferred to a smaller circle of Member States.

Using the instrument of Closer Co-operation, deadlocks in legislation procedures can be better circumvented in the future. However, the „quasi-veto“ of the Member States mentioned above continues to exist.(71) Depending on the interpretation, the procedure may require ,quasi-unanimity“ or a qualified majority restricted by the veto in practice.

But the basic suitability of Closer Co-operation for resolving deadlocks within the framework of procedures requiring unanimity should not divert our attention from the fact that it is also permitted in cases requiring ,only“ a qualified majority. There may be situations in which some Member States do not participate themselves in Closer Co-operation, but are ready to agree to it.

\subsection{Product-related Regulations}

At a national and European level, environmental regulations frequently address the product properties of goods.(72) Basically, we have to differentiate product regulations in the harmonised area, where secondary law has already been adopted, from those in the non-harmonised area.

The legal requirement established by the Treaty of not affecting the ,acquis communautaire“ is relatively unproblematic in the establishment of product standards in the non-harmonised area because secondary Community law does not exist as yet. As mentioned above, Closer Co-operation in the non-harmonised area has to be orientated to the principles of the Treaty, just like national measures.(73) In the field of product regulations, the prohibition of quantitative restrictions or other measures to the same effect is of particular relevance.(74) Like national regulations, measures violating this prohibition may be justified for environmental reasons.(포)

As mentioned above, the biggest legal obstacle to the practical application of the new instrument is the prohibition of discrimination or restriction of trade and of distortions of competition laid down in Article 11 (1) (e) TEC. Discrimination or a restriction of trade could already exist if the ,ins“" introduce stricter product standards and the products manufactured by the „outs" that do not comply with these standards must not be sold in the ,ins“. Therefore, a strict interpretation of this clause would preclude the applicability of Closer Co-operation especially in the field of products.

But the new instrument of Closer Co-operation opens up a new opportunity for action to the Member States interested: Among themselves, they may define a common standard that forms the basis for market access to products from the countries participating in Closer Co-operation. Thus, if a product standard cannot be adopted at the Community level, the leaders may form a group to establish Closer Co-operation and define a high environmental protection level for their territories.

Non-discrimination can be achieved by limiting the application of the high environmental standards only to products from the Member States participating in Closer Co-operation. The products manufactured in the „outs“ may continue to comply with the relevant national regulations. Within the framework of Closer Co-operation, the extent of the economic disadvantage of domestic manufacturers is clearly lower than in case of a national regulation.

The application of Closer Co-operation to product regulations in a field where Community regulations already exist is even more difficult from a legal perspective than in the non-harmonised field. A group of Member States interested in achieving a protection standard higher than the one existing at the Community level has to make the measures compatible not only with higher-ranking primary law (like in the non-harmonised field), but also to existing secondary law. Closer 
Co-operation in this field may only establish stricter provisions. Additionally, the prohibition of discrimination and distortions of competition is to be observed as well. Here, the statements made for the non-harmonised field also apply. A strict interpretation of Article 11 (1) (e) TEC would preclude the application of Closer Co-operation in practice. But also with regard to product standards already harmonised at the Community level, the new opportunity for action outlined above exists. If product standards cannot be raised at the Community level, the ,pioneering countries“ may join to establish Closer Co-operation and define a higher protection standard for their jurisdictions based, however, on the Community regulations. Discrimination is prevented by applying the lower, Community-wide standards to products made in the „outs“.

In practice, the pioneering states will be interested in Closer Co-operation under these circumstances only if the crucial production countries are interested in it and if continuing preferred access for products from non-participants is not expected to lead to a significant growth of their market share. However, some Member States may also be motivated to accept economic disadvantages resulting from higher product standards for a limited period of time and to a certain extent if they expect to achieve, for example, a competitive edge by playing the role of technological ,pace-setters“. ( $\underline{76})$

On the whole, we can state that the prohibition of discrimination and distortion of competition considerably restricts the application of Closer Co-operation in the field of product standards. But the adoption of higher product standards seems to be possible, also taking into account economic aspects, if they only apply to the ,ins“ (and, thus, do not result in discrimination). When the majority of Member States joins forces, the economic disadvantages usually related to actions by a single country are reduced.

\subsection{Process Regulations}

In addition to product regulations, process standards( $\underline{77})$ also play an important role in the environmental field. The legal requirements of Closer Co-operation defined in the Treaty have a less restricting effect on the regulation of process-related measures than in the field of product regulation since process-related measures affect the internal market only indirectly.

The strictest criterion that basically could prevent the applicability of Closer Co-operation in this field is the requirement that the measures must not distort the conditions of competition between the Member States.(8) As outlined above,(⒐7) this requires that objectively intensive and sustained adverse effects act on the common market. Thus, distortion of competition does not exist if environmental measures raise the production costs in an industry. Therefore, the legal requirements do not basically restrict the practical applicability of Closer Co-operation in the field of process regulations.

The application, however, significantly depends also on the economic interests of the actors involved. Tensions exist in the field of process regulations and internal market. National process regulations impose additional duties on domestic manufacturers that may raise production costs and, hence, result in a disadvantage for the manufacturers at the European and international market.(0ㅡ) The more intensive competition is in a sector and the higher the cost pressure is, the more difficult it will be for a ,pioneering country“ to adopt environmental process regulations at a national level. In contrast, environmental laggards tend to be interested in offsetting other, potentially unfavourable production factors, such as market distance or relatively low productivity, by lower process standards in order to raise their competitiveness. They are not interested in the harmonisation of process standards. These conflicting interests usually mean that European minimum standards for production 
processes cannot be achieved or are defined at a low level in many cases.

Against this backdrop, Closer Co-operation offers environmental leaders the opportunity to set a high standard in the territory of the Member States involved. Thereby, they can offset part of the negative economic impact that national measures would have. As a result, two different minimum standards would exist that applied to different groups of countries. Since countries not involved in such a Closer Co-operation would not suffer a disadvantage (maybe they would even have an advantage due to raised production costs in the high-standard countries), they would probably not oppose Closer Co-operation within the framework of the authorisation procedure initiated by the other Member States. A majority of pioneering states, however, is only likely to be achieved for the definition of higher process standards if the expected economic impact of the two standards do not exceed an economically supportable level. To this effect, all the manufacturing countries crucial for the field to be regulated whose other production factors are comparable would have to commit to the higher standard.

It is to be stated that there is a great potential for increased flexibility in the field of production-related regulations in environmental policy.(181) For example, it is conceivable that the standards for large combustion plants can be raised ,unilaterally“ or the scope of the existing directive can be extended within the framework of Closer Co-operation if the related proposal( $\underline{82})$ should fail at the European level. $(\underline{83})$

A possible test case of Closer Co-operation in the environmental field could be the taxation of energy products that is heavily contested at the European level today. Though the tax is to be applied to energy products, this type of taxation is in line with the logic of process regulations since the costs will be incurred in the production process in the countries collecting the tax. The discussion on the Commission's proposal on the harmonisation of certain energy products( $\underline{84})$, such as diesel, gas oil, kerosene or electricity, has lost momentum at the European level, in particular due to the objections of Spain. $(\underline{85})$ When this proposed directive is put to a vote in the Council, it is to be feared that unanimity, as required by the Treaty, will not be achieved. The Dutch Finance Minister Gerrit Zalm already proposed that this field be regulated only by like-minded Member States, however without reference to the instrument of Closer Co-operation. $(\underline{86})$ If the Member States do not change their opinion, the necessary qualified majority could be achieved for submitting the request to the Commission. Whether the qualified majority in the Council can be reached and, in particular, whether a potentially not participating Member State will put a „quasi-veto“ on the proposal will depend on the concrete wording.

In this context, environmental liability could also be discussed. The category to which environmental liability belongs depends on the fact whether it applies to production facilities or product properties. Thus, environmental liability follows a mixed logic. But in the field of environmental liability, Closer Co-operation is likely to come about only if a procedure has failed at the European level. The white paper on environmental liability that has been discussed for a longer period of time (also due to delays caused by the change in the European Commission) only exists in the form of a draft. However, the discussion process might be speeded up by the awareness of the new instrument of Closer Co-operation.

\subsection{Other Regulations}

A considerable potential for Closer Co-operation seems to exist in the fields in which major effects on the internal market are not to be feared. This relates, on the one hand, to environmental 
regulations concerning administrative procedures or court proceedings and, on the other hand, to measures in the field of nature conservation and the protection of biodiversity. In particular, the proposal for a directive on the strategic environmental impact assessment, on whose possible legal basis a heavy dispute is going on, $(\underline{87})$ could meet the criteria for Closer Co-operation and achieve the required majority in the Council. $(\underline{88})$

In the field of nature conservation and the protection of biodiversity, Closer Co-operation could possibly serve as a model and contribute to the dissemination of successful regulation concepts to the entire Community territory. Member States that still hesitate would always face the example of the countries participating in Closer Co-operation, which would constitute an orientation for the gradual development of their own environmental policy.

\subsection{Implementation of International Agreements}

An analysis is to be performed in order to examine whether Closer Co-operation can be used in the implementation of international agreements by Member States of the European Union.

The protection of Community assets is regulated in many cases outside the Community framework by the form of international agreements. This is essentially due to the fact that the group of the countries concerned is not identical to the group of the Member States of the European Union. Here, two cases can be distinguished: (1) geographical incongruity and (2) incongruity in terms of substance. The former includes, for example, the protection of regional and sub-regional areas such as the North Sea, Baltic Sea, the Rhine or the Alps. The latter refers to issues where not all the Member States are affected by the contents of the international agreement and, hence, do not have the motivation to accede to it.(9) The forthcoming eastern enlargement will further increase incongruities in terms of geography and substance.

There are, however, also cases in which the signatories of international environmental protection agreements commit to the implementation of a protection level that is higher than the one achievable with all Member States at the European level. These include the Convention on the Conservation of Migratory Species of Wild Animals, $(\underline{90})$ the Convention on the Protection of the Marine Environment of the North East Atlantic( $\underline{91})$ and the Convention on Civil Liability for Damage Resulting from Activities Dangerous to the Environment.(2)

The legal requirements laid down in the EC and EU Treaties have to be observed by the Member States concerned when implementing international agreements. In cases where only part of the Member States are affected for geographical reasons, it seems to be problematic that the majority of the Member States has to join forces. In some cases (e.g. the protection of the Mediterranean Sea, Baltic Sea or the Alps, this criterion will be difficult to meet, also and precisely because of the forthcoming eastern enlargement. The implementation of measures within the framework of the Convention on the Protection of the Marine Environment of the North East Atlantic (OSPAR), however, is relevant because the Convention has been signed not only by adjoining states, but also by Member States located at rivers flowing into the North Eastern Atlantic. In all these fields, we have to bear in mind that a procedure at the Community level based on the EC Treaty needs to have failed before Closer Co-operation can be initiated.

But if these conditions are fulfilled, the instrument of Closer Co-operation offers the possibility to shift trans-boundary environmental protection further into the institutional framework of the Community. The main advantage for the Member States involved would be that they will be able to 
use the highly advanced and comparably successful institutional decision-making mechanisms (e.g. involvement of the Commission, monitoring by the Court of Justice, Council votes by qualified majority, etc.) for promoting collective decision-making in this way. Then, environmental policy would no longer be orientated merely to achieving standards that are as uniform as possible and apply all over the Union. Additionally, it would be geared to finding ,tailored“ solutions to specific environmental problems that previously had to be tackled outside the Community framework.

The mechanism of Closer Co-operation could also be helpful,(3) if the Community intends to participate in international agreements in addition to a part of the Member States, while some Member States declare in advance that they do not wish to comply with the related obligations within the framework of the Community. Provided that the provisions laid down in the EC and EU Treaties are observed, the Community could accede to the international agreement and implement it only within the framework of Closer Co-operation with a majority of Member States.

In the context of the ratification and implementation of the Kyoto Protocol by the Member States of the Union, a detailed examination of the applicability of Closer Co-operation should be considered. Against the background of the accession of at least five Central and Eastern European Countries (CEECs) to the European Union, the differences in the reduction commitments of the individual Member States will became even more marked. The efforts and the capabilities of the candidate countries to achieve the reduction duties applicable to them can probably not be compared with those of the majority of the current Member States. Closer Co-operation could perhaps contribute to ensuring a flexible solution for the implementation of the different obligations. But even before the enlargement, it is conceivable within the framework of EC burden sharing that some Member States join to create a legal framework for emissions trading, while others implement their reduction obligations by national measures. In particular in the context of the implementation of the Kyoto Protocol, Closer Co-operation by the majority of Member States seems to be topical for the creation of a uniform framework for the further harmonisation and increase of taxes on energy products, which is currently under heavy debate at the Community level.

On the whole, international agreements on environmental protection can give rise to considerations on the application of Closer Co-operation. It will be possible to clarify only in each individual case whether an international agreement can best be implemented by non-harmonised national measures, Community legislation or rather by Closer Co-operation within the institutional framework of the Community.

\subsection{Closer Co-operation and Eastern Enlargement}

In the course of the forthcoming enlargement of the European Union,(94) a number of countries will accede to the EU that, in all likelihood, rather belong to the environmental ,laggards“.(95) The following considerations focus on the question of in how far Closer Co-operation can contribute to a new dynamism in European environmental policy in the face of enlargement or at least to the maintenance of the environmental status quo.

At first, basic aspects of the problems involved in enlargement with regard to European environmental policy will be briefly presented. The potential environmental impact of Closer Co-operation is examined against this backdrop using two crucial factors: the planned reform of the decision-making rules of the Community and differences between groups of candidate countries. Finally, we analyse the questions whether new Member States have to join a Closer Co-operation already existing at the time of their accession and which effects enlargement could have on existing 
cases of Closer Co-operation.

\subsubsection{Problems of Enlargement}

Eastern enlargement constitutes a challenge for environmental progress in the Community. On the one hand, the existing deficit in the practical application and enforcement of European environmental law may be exacerbated.(6) As the European Commission stated in its annual reports on the progress of the candidate countries towards accession,(97) major deficits still exist in the candidate countries both with regard to the formal transposition of Community legislation and to its implementation and enforcement, in particular in the environmental field. Therefore, a limited number of transition periods will probably be necessary for completely taking over European environmental law.(98) On the other hand, there is the risk of an obstruction of further environmental progress after the accession since the number of environmental ,laggards" will grow among the Member States in the course of enlargement.(99)

We can assume that the exacerbation of the implementation deficit is related to the protection level provided by the environmental standards of the Community. If the protection level is raised at the European level, an increase in the implementation deficit is to be expected at a national level and vice versa.(100) Since the candidate countries lack both financial and administrative capacities and the original political will for putting high standards of environmental protection into practice, $(101)$ the relation between regulation level and implementation deficit is probably very close in these countries, which could become an obstacle to further progress in the Community's environmental policy. In the course of enlargement, the Community might face the dilemma of either having to lower its environmental regulation level or having to accept further implementation deficits. Either option would not only adversely affect environmental protection in Europe, but also reduce the credibility and empirical legitimacy of European environmental policy in the long term. A tendency towards the „re-nationalisation“" of European environmental policy could be one of the possible consequences. $(\underline{102})$

Against this backdrop, Closer Co-operation could create opportunities for partly de-coupling the connection between implementation deficits and regulation levels and, at the same time reduce the growing risk of an obstruction of a high protection level by the increasing number of „laggards“.

\subsubsection{The Influence of Institutional Reforms}

The discussion of the impact that Closer Co-operation will have on environmental policy in the context of enlargement still involves uncertainties at present. Last not least, this is due to the fact that the effects will strongly depend on the future arrangements for decision-making processes in the European Union. The Amsterdam Treaty stipulates that, at the latest one year before the EU will have more than twenty Member States, an intergovernmental conference has to be convened to initiate necessary institutional reforms. $(\underline{103})$ For the environmental policy of the Community, the following two options will probably be of great importance: the extension of qualified majority voting to additional provisions of the Treaty, which is under discussion, and the modification of the weighting of votes and/or blocking minorities for decisions of the Council that are taken by qualified majority. If the current rules were maintained, the present candidate countries would have a blocking minority in the Council after their accession.(104) If the environmental laggards among today's Member States $(\underline{105})$ are taken into account as well, it is obvious that the chances of an obstruction of advanced environmental regulations would significantly rise. 
Thus, taking resort to Closer Co-operation could be helpful in several ways. If the intergovernmental conference should not adopt reforms that can maintain decision-making efficiency roughly at the same level as today, Closer Co-operation could allow the majority of states to circumvent obstructionism. They could take measures corresponding to a protection level that would have been blocked by the laggards in the conventional legislation procedure.

But even if institutional reforms are adopted that more or less permit the maintenance of the present decision-making efficiency there could be fields for the application of Closer Co-operation. Given the increase of environmental laggards among the Member States upon enlargement, it is to be assumed that the overall protection level will decline even if the current decision-making efficiency is maintained. The reason for such a development is the fact that constant decision-making efficiency paralleled by a deterioration in the quantitative relation between leaders and laggards has not only positive effects: The number of cases in which environmental laggards will be able to benefit from higher decision-making efficiency would increase as compared with today.(106) Therefore, it would again be conceivable that Closer Co-operation could permit the majority of Member States to adopt a higher protection level.

However, if the present decision-making efficiency is maintained, also the pioneering states could continue to expect - in spite of the overall improvement of the laggards' position over today — that they will be able again and again to achieve decisions in favour of a higher protection level.(107) But as outlined above, there is the risk that the implementation deficits will continue to rise for measures aiming at a relatively high protection level, in particular after enlargement. Thus, in certain cases, it could be advantageous for environmental policy to adopt higher regulation standards not for all the countries, but only for the majority of states within the framework of Closer Co-operation that can also be expected to adequately implement them.

\subsubsection{Differences between the Candidate Countries}

As described in Sections 2.4.1 and 4, the application of Closer Co-operation will probably have only minor adverse effects on the homogeneity of legislation and the political integration process. With regard to enlargement, this statement, however, has to be qualified somewhat. In the course of enlargement, it is to be expected that the differences between the future Member States, in particular in terms of economic performance, will increase to an extent hitherto unknown.(108) While the economic gap between the present Member States and the candidate countries of the "first wave“ (Estonia, Poland, Slovenia, Czech Republic, Hungary and Cyprus) still seems to be comparable with the relevant differences that characterised the enlargement of the European Community to the South, further accessions - for example by countries like Romania or Bulgaria — could involve a new quality of differences.

For the field of environmental policy, this new quality would mean that a third group of ,late laggards" could form within the European Union after the accession of countries like Romania or Bulgaria. This group would differ from the laggards in two respects: Firstly, environmental traditions and, in particular, the financial and administrative capacities of the countries concerned for the implementation and enforcement of European environmental legislation would be even more limited than, for example, those of the candidate countries of the first wave. Secondly, the potential ,late laggards" either do not border on present Member States or they essentially border on laggard states. For this reason, only little environmental impetus is to be expected from trans-border Co-operation for the group of ,late laggards“. 
In this situation, the environmental benefits of Closer Co-operation would be doubtful. On the one hand, Co-operation aiming at a high protection level would involve the danger that the „late laggards" probably would hardly be able to catch up with the participants of Closer Co-operation without outside help within a reasonable period of time. On the other hand, it would be difficult in political practice after the accession of the present twelve official candidate countries to achieve the simple majority of Member States required for the initiation of Closer Co-operation without the involvement of some laggards. In this case it is doubtful whether Closer Co-operation can lead to a protection level that is significantly higher than in the conventional legislation procedure with qualified majority voting.

In total, Closer Co-operation is an instrument that may help to limit the lowering of the protection level in the wake of the enlargement of the European Union. Given the restrictive prerequisites for its establishment and the above limits to its benefits, Closer Co-operation, however, has to be supplemented by further instruments, in particular flexible provisions in secondary environmental law and more flexibility in implementation in order to prevent a reduction of the protection level as far as possible.(109)

\subsubsection{Enlargement and Existing Cases of Closer Co-operation}

The accession to the European Union implies the transposition of the ,acquis communautaire“. This raises the question as to whether the candidate countries would be obliged to take over a Closer Co-operation that already exists at the time of their accession. Since the authorisation decision for Closer Co-operation is taken by all the Member States, it is included in the ,acquis communautaire“. However, this does not mean that the candidate countries would have to participate in Closer Co-operation. The opinion that participation in Closer Co-operation does not form part of the transposition of the ,acquis communautaire“ is supported by the fact that not all the „old“ Member States participate in Closer Co-operation. Moreover, the implementation provisions of Closer Co-operation, which also had to be taken over in case of participation, have not been adopted by all the Member States.

Furthermore, it was obviously assumed also in the northern enlargement of the European Union that the Schengen Agreement, which is generally considered to be a forerunner of Closer Co-operation,(110) did not form part of the ,acquis communautaire“ and, hence, did not have to be automatically transposed by the then candidate countries. At least the agreement contains a clause that explicitly states that it has to be taken over by new Member States of the Union (Article 8 of the Schengen Protocol).

Article 43 (1) TEU states that the institutions, procedures and mechanisms of the Community may only be used for Closer Co-operation provided that it concerns the majority of Member States. In some cases, this majority might be lost after the enlargement of the Union if the candidate countries would not join the Closer Co-operation. For practical reasons, it may therefore be necessary to regularly include a participation obligation for candidate countries in the relevant authorisation decision.

\section{Impact on the Integration Process}

The long-term impact of Closer Co-operation on the integration are still difficult to assess at present since it will significantly depend on factors such as the forthcoming institutional reforms and the speed of enlargement. There are, however, signs indicating that Closer Co-operation will accelerate 
the integration process without considerably affecting the homogenous legal area and without a permanent split of the Community. At the same time, it offers opportunities for supporting a high protection level in the field of environmental protection. Three factors speak for this assessment: the ,threatening effect" of Closer Co-operation, its pull effect and the interests of the European institutions and the ,ins“.

\section{1 ,Threatening Effect" of Closer Co-operation}

One reason why Closer Co-operation is expected to have only minor effects on the homogenous legal area is the fact that its ,threatening effect" alone could suffice to ensure that the potential participants achieve satisfactory political results. In this case, the actual application of the instrument would not be necessary. Due to the ,threatening effect“", the potential participants could succeed, for example, in adopting a higher environmental protection level in the conventional legislation procedure at the European level.

The ,threatening effect" of Closer Co-operation depends on various influencing factors. Firstly, it is to be assumed that it will the bigger, the less effective the „quasi-veto" of the Member States against the establishment of Closer Co-operation turns out to be in practice.(111) Moreover, non-participation in Closer Co-operation may be linked to the loss of political prestige and might be associated, in particular, with the status of a „second-rate“ Member State. Finally, the „outs“ may also have to bear additional political and economic costs. These essentially correspond to the ones that also give rise to the pull effect of Closer Co-operation (see next section).

Whether Closer Co-operation generates an adequate ,threatening effect“" or whether it only exerts a pull effect after its establishment also depends on the concrete circumstances and political interests involved.

\subsection{Pull Effect of Closer Co-operation}

Closer Co-operation may result in economic effects that also prompt manufacturers based in countries not participating in the Co-operation to comply with the higher regulation level for their entire production. In this context, decisive factors include the size of the markets in the ,ins" $(\underline{112})$ and the extent of additional costs of separate production for „,ins“ and „outs“.(113) Moreover, the costs of taking over the higher regulation level go down in the course of time since the initially high investment in the development of new technologies and processes significantly decrease. This facilitates the later accession of the ,outs“. Apart from these factors, non-participation may also result in additional costs for the ,outs“, in particular with regard to catching up with technological developments. But also the demand of final consumers may shift towards more environmentally friendly products and production processes corresponding to the protection level of Closer Co-operation.

In addition to economic costs, the „outs“ may also have to bear administrative and political costs. By means of Closer Co-operation, the ,ins “ create political and administrative facts that can hardly be reversed in the Community since the relevant regulations have already been adopted and applied in practice by the majority of Member States and the European Commission. If the „laggards" also wish to catch up with the higher regulation standards, they will, therefore, have to take over the regulations of Closer Co-operation or at least have to strongly orientate to them. The latecomers face the problem that they cannot considerably modify the type and level of the regulation in whose adoption they were not involved safe for the authorisation decision for Closer Co-operation. The consequences may 
be severe since the rules of Closer Co-operation are geared to the political interests, administrative traditions and technological conditions in the states that established the Closer Co-operation.(114)

These effects result not only in a strong ,threatening effect“" of Closer Co-operation, but also provide an incentive for the „outs“ to join Closer Co-operation as soon as possible since this is the only way to influence the further elaboration of the regulations.

\subsection{Interests of the European Institutions and the ,Ins“ ${ }^{64}$}

The crucial European institutions not dominated by the Member States, i.e. Commission, Parliament and Court of Justice, have a strong institutional interest in preventing a sustained split of the Community. Therefore, if the homogeneity of the legal area is at risk due to Closer Co-operation, it is to be expected that the institutions will take measures countering that tendency. For example, the „outs" could be given assistance permitting them to catch up with the ,ins“ relatively soon. Within the framework of its central role in the preparation of the proposal for Closer Co-operation, the Commission could try to include measures to that effect.(115) The Parliament could analogously use its influence on the implementation decisions of a Closer Co-operation. Furthermore, the Commission decides on the participation of additional Member States in a Closer Co-operation. By a generous interpretation of the requirements, it could mitigate the risk of a split of the Community.

Finally, it is to be expected that, in many cases, the ,ins“ will be interested in preventing a permanent split of the regulation level. This will particularly apply if the lower regulation level of the ,outs“ gives them a competitive edge in business. In order to avoid sustained competitive disadvantages, the ,ins" may well be ready to provide financial assistance to the „outs" so that they can catch up with the higher regulation level.

In spite of the imponderabilities outlined above, the overall assessment of Closer Co-operation is positive, both with regard to the integration process and support to a high protection level in the environmental field. Closer Co-operation seems to be unlikely to cause the erosion of the homogenous legal area and a split of the Community. On the one hand, Closer Co-operation could generate a „threatening effect" that, sometimes, may render its application unnecessary. Moreover, it is to be expected that the number of participants in a Closer Co-operation will probably increase soon due to its pull effect. Finally, there are significant incentives both for the European institutions and the „ins“ to counter tendencies towards a sustained split by intensified support to the „outs“. This should also allow the latter to participate in Closer Co-operation.

\section{Conclusions}

The prerequisites laid down in the Treaty for the implementation of Closer Co-operation require further interpretation in some cases, but this does not preclude the instrument's practical applicability in European environmental policy. The interpretation of the remaining uncertain issues will be decisively influenced by the actors involved, e.g. the European Commission, the Member States and the European Court of Justice. A clarification within the framework of the next intergovernmental conference, however, would be advantageous since this could raise legal certainty. The legal requirements permit the application of Closer Co-operation not only to entire policies but also to individual legislative acts that cannot achieve the required majority at a European level, be it unanimity or qualified majority. Against this backdrop, Closer Co-operation particularly provides the opportunity to reduce cases of obstruction in the environmental field. 
In environmental policy, potential fields of application for Closer Co-operation basically are product or process standards, regulations in the field of nature conservation and the promotion of biodiversity, administrative procedures as well as the implementation of international agreements on environmental protection. The application of Closer Co-operation to environmental product standards is relatively restricted due to the internal market regulations. Since process-related regulations have less effect on the internal market, this field of application is bigger.

The instrument of Closer Co-operation offers a new opportunity to further advance the European integration process. The risk of a sustained split of the regulation level is practically limited by the fact that there are manifold incentives for the countries not participating in Closer Co-operation to catch up with the „leaders“ relatively soon. At the same time, the European institutions and the participants of Closer Co-operation are interested in enabling the „outs“ to take over the regulation level of the Closer Co-operation.

From the perspective of environmental policy as well as from the viewpoint of the integration process as such, the new instrument of Closer Co-operation is assessed positively on the whole. In particular with regard to the forthcoming enlargement of the European Union, the speedy utilisation of the new instrument should be considered. Since the agreement of the Member States required for the authorisation decision will be more difficult to achieve after the accession of additional countries, the current membership offers the unique opportunity to use Closer Co-operation in the further development of environmental policy, thus serving both European integration and the protection of the environment, nature and resources in Europe.

\section{References}

Albin, S. and S. Bär 1999: "Nationale Alleingänge nach Amsterdam - Der neue Artikel 95 EGV: Fortschritt oder Rückschritt für den Umweltschutz?" Natur und Recht, No. 4, p. 185-192.

Bär, S. and R. A. Kraemer 1998: "The Environmental Impact of the Treaty of Amsterdam." European Environmental Law Review, Vol. 10, No. 2, p. 315-330.

Becker, U. 1998: "Differenzierung der Rechtseinheit durch "'abgestufte Integration" EuR, Supplement 1, p. 29-57.

Berg, W. and R. Karpenstein 1998: "Änderungen der rechtlichen Grundlagen der EU durch den Vertrag von Amsterdam." EWS, Vol. 9, No. 3, p. 77-83.

Bergmann, J. and C. Lenz (eds.) 1998: Der Amsterdamer Vertrag, Eine Kommentierung der Neuerungen des EU - und EG-Vertrags. Cologne: Omnia Verlag.

Carius, A., I. v. von Homeyer and S. Bär1999a: Die umweltpolitische Dimension der Osterweiterung der Europäischen Union: Herausforderung und Chancen, Endbericht im Auftrag des Rates von Sachverständigen für Umweltfragen. Berlin: Ecologic, Gesellschaft für Internationale und Europäische Umweltforschung.

Carius, A., I. v. Homeyer and S. Bär 1999: "Die Osterweiterung der Europäischen Union Herausforderung und Chance für eine gesamteuropäische Umweltpolitik". In Politik und Zeitgeschichte, supplement of the weekly Das Parlament, 48/99.

Carius, A., I. v. Homeyer and S. Bär, 2000, "The Eastern Enlargement of the European Union and 
Environmental Policy: Challenges, Expectations, Multiple Speeds and Flexibility." in: Holzinger, K. and Koepfel, P. (eds.): Environmental Policy in a European Union of Variable Geometry? The Challenge of the Next Enlargement. (Basel: Helbig \& Lichtenhahn).

Chaltiel, F. 1998: „Le Traité d'Amsterdam et la coopération renforcée“. Revue du Marché Commun et de l'Union européenne, No. 418, p. 289 - 293.

Constantinesco, V. 1997: "Les clauses de 'coopération renforcée', le protocole sur l'application des principes de subsidiarité et de proportionalité.,, RTD eur, Vol. 33, No. 4, p. 751-767.

Demmke, C. (ed.) 1998: Europäische Umweltpolitik und nationale Verwaltung. Maastricht: European Institute of Public Administration.

Devuyst, Y. 1997: "The Treaty of Amsterdam: An Introductory Analysis." ECSA REVIEW, Vol. 10, No. 3, p. 6-14.

Duff, A. (ed.) 1997: The Treaty of Amsterdam. London: Federal Trust.

Ehlermann, C. D. 1997: "Engere Zusammenarbeit nach dem Amsterdamer Vertrag: Ein neues Verfassungsprinzip?" EuR, No. 4, p. 362-397.

Emmert, F. 1996: Europarecht. Munich: Beck.

Epiney, A. 1997: Umweltrecht in der Europäischen Union. Cologne, Berlin: Carl Heymanns Verlag.

Epiney, A. 1998: "Schengen - ein Modell differenzierter Integration", in: F. Breuss and S. Griller (eds.): Flexible Integration in Europa - Einheit oder "Europa á la carte"? Vienna: Springer Verlag.

Epiney, A. 1998: "Neuere Tendenzen der Rechtsentwicklung in der Europäischen Union." SZIER, No. 3, p. 396-405.

Epiney, A. 1999: "Flexible Integration und Umweltpolitik in der EU - rechtliche Aspekte", in: K. Holzinger and P. Koepfel (ed.): The Challenge of the Next Enlargement. Basel: Helbig \& Lichtenhahn. In print.

European Commission 1999a: 1999 Regular Report from the Commission on the Czech Republic's Progress towards Accession. (Brussels: European Commission).

European Commission 1999b: 1999 Regular Report from the Commission on Estonia's Progress towards Accession. (Brussels: European Commission).

European Commission 1999c: 1999 Regular Report from the Commission on Hungary's Progress towards Accession. (Brussels: European Commission).

European Commission 1999d: 1999 Regular Report from the Commission on Poland's Progress towards Accession. (Brussels: European Commission).

European Commission 1999e: 1999 Regular Report from the Commission on Slovenia's Progress towards Accession. (Brussels: European Commission).

Gaja, G. 1998: "How Flexible is Flexibility Under the Amsterdam Treaty?" Common Market Law Review, Vol. 35, No. 4, p. 855-870. 
Gehring, T. 1998: "Die Politik des koordinierten Alleingangs." Zeitschrift für internationale Beziehungen, Vol. 5, No. 1, p. 43-78.

Gil-Robles, J. M. 1997: "Die Flexibilität, ein Mechanismus für eine verstärkte Integration." EuZW, Vol. 8, No. 12, p. 353.

Hall, P. 1998: "Verstärkte Zusammenarbeit - Flexibilität", in: J. Bergmann and C. Lenz (eds.): Der Amsterdamer Vertrag - Eine Kommentierung der Neuerungen des EU- und EG-Vertrages. Cologne: p. 331-342.

Héritier, A. 1994: "Leaders" and "Laggards" in European Policy-Making. Clear-Air Policy-Changes in Britain and Germany. Convergence or Diversity? The Pressure of Internationalization on Economic Governance. Institutions and Policy Outcomes. Aldershot: Avebury.

Janning, J. 1994: "Europa braucht verschiedene Geschwindigkeiten." Europa-Archiv, Part (?) 18, p. $527-535$.

Janning, J. 1997: "Dynamik in der Zwangsjacke - Flexibilität in der Europäischen Union nach Amsterdam." Integration, Vol. 20, No. 4, p. 285-304.

Jordan, A. J. 1999:, "The Implementation of EU Environmental Policy: A Policy Problem Without a Political Solution?", Environment and Planning C: Government and Policy, 17/ 1: 69-90.

Kortenberg, H. 1998: "Closer Co-operation in the Treaty of Amsterdam." Common Market Law Review, Vol. 35, No. 4, p. 833-854.

La Serre de, F. and H. Wallace 1997: "Les coopérations renforcées : une fausse bonne idée?" Notre Europe, No. 2, p. 5-43.

Labayle, H. 1998: "Amsterdam ou l'Europe des coopérations renforcées." Europe Editions du Juris Classeur, No. 3, p. 4-7.

Lahr, R. 1983: "Die Legende vom Luxemburger Kompromiß." Europa Archiv, Vol. 38, No. 8, p. 223-232.

Martenczuk, B. 1998: "Die differenzierte Integration nach dem Vertag von Amsterdam." ZEuS, No. 4, p. 447-474.

Monar, J. 1997: "Schengen and Flexibility in the Treaty of Amsterdam: Opportunities and Risks of Differentiated Integration in EU Justice and Home Affairs", in: de Boer M. (ed.): Schengen, Judicial Co-operation and Policy Coordination. Maastricht: European Institute of Public Administration. p. 9-29.

Mosler, H. 1966: "National- und Gemeinschaftsinteressen im Verfahren - Die Beschlüsse der außerordentlichen Tagung des EWG-Rates in Luxemburg vom 29. Januar 1966." ZaöRV, Vol. 26, No. 1, p. 1-32.

Müller-Brandeck-Bocqet, G. 1997: "Flexible Integration, Chance für die europäische Umweltpolitik?" Integration, Vol. 20, No. 4, p. 292-303.

Philippart, E. and Edwards, G. 1999: "The Provisions on Closer Co-operation in the Treaty of Amsterdam: The Politics of Flexibility in the European Union." Journal of Common Market Studies, Vol. 37, No. 1, p. 87-108. 
Schitty, D. 1997: "Fortgang der europäischen Integration." Gemeinsamer Diskussionsbeitrag des deutschen und des französischen Außenministers, Klaus Kinkel und Hervé de Charette, für die Regierungskonferenz zur verstärkten Zusammenarbeit. Internationale Politik, No. 3, p. 69-71.

Schönfelder, W. and R. Silberberg 1997: "Auf dem Weg zum Ziel: Die Ergebnisse des Vertrags von Amsterdam." Internationale Politik, No. 11, p. 18-24.

Schweitzer, M. 1976: "Die Stellung der Luxemburger Vereinbarung im Europäischen Gemeinschaftsrecht", in: F. Burkei and D. Polter (eds.): Rechtsfragen im Spektrum des Öffentlichen Mainzer Festschrift für Hubert Armbruster. Berlin: Duncker \& Humblot, p. 75-94.

Shaw, J. 1998: "The Treaty of Amsterdam: Challenges of Flexibility and Legitimacy." European Law Journal, Vol. 4, No. 1, p. 63-86.

Streinz, R. 1984: Die Luxemburger Vereinbarung. Munich: Verlag V. Florenz.

Streinz, R. 1999: Europarecht. Heidelberg: C. F. Müller Verlag.

Stubb, A. 1996: "A Categorization of Differentiated Integration." Journal of Common Market Studies, Vol. 34, No. 2, p. 283-295.

Thun-Hohenstein, C. and F. Cede (eds.) 1995: Europarecht. Vienna: MANZ Verlag.

Tsatsos, D. (ed.) 1999: Verstärkte Zusammenarbeit. Flexible Institutionen oder Gefährdung der Integration? Baden Baden: Nomos.

Ukrow, J. 1998: "Die Fortentwicklung des Rechts der Europäischen Union durch den Vertrag von Amsterdam." ZEuS, No. 2, p. 144-155.

Vasey, M. 1988: "Decision-making in the Agriculture Council and the 'Luxembourg compromise'". Common Market Law Review, Vol. 25, No. 4, p. 725-732.

Von Homeyer, I., A. Carius and S. Bär: "Consequences of Eastern Enlargement of the European Union for European Environmental Policy-Making", in: Maria G. Cowles and Michael Smith (eds.): State of the European Union: Risks, Reforms, Resistance and Revival. Oxford: Oxford University Press. In print.

Von Homeeyer, I., L. Kempmann and A. Klasing: "EU Enlargement: Screening Results in the Environmental Sector". Environmental Law Network International (ELNI) Newsletter. In print.

Von Meijenfeldt, H. G. 1997: "Vergroening van Verdrag van Amsterdam." Milieu \& Recht, No. 9, Rz. 174-178.

Wallace, H. and W. Wallace 1995: Flying Together in a Larger and More Diverse European Union. Den Haag: Netherlands Scientific Council for Government Policy.

Weiler, J.H.H. 1997: "Amsterdam, Amsterdam." European Law Journal, Vol. 3/97, p. 309-312.

Wessels, W. 1998: "Verstärkte Zusammenarbeit: Eine neue Variante flexibler Integration", in: M. Jopp, A. Maurer and A., Schmuck, O. (eds.): Die Europäische Union nach Amsterdam. Bonn: Europa Union. 


\section{Endnotes}

(1) The analysis has been published by the Federal Ministry of Environment, Youth and Familiy Affairs, Closer Co-operation in European Environmental Policy after Amsterdam, Band 32/1999, Schriftenreihe des BMUJF.

(2) Cf., in particular, A. Stubb, Journal of Common Market Studies 2/1996, who identified and categorised 61 different terms in English, French and German used in this discussion.

(3) „Lamers-Schäuble Manifesto“ of the CDU/CSU Group in the Bundestag, Bonn, 1 September 1994.

(4) H. Wallace / W. Wallace, 1995, p. 56.

(5) However, the proposal submitted by the Member States (cf. A. Duff, 1997) and by European institutions, in particular the European Parliament (cf. D. Tsatsos, 1999), have to be taken into account as well.

(6) At the Community level, environmental product standards are usually adopted on the basis of Article 95 EC Treaty. More stringent national measures must comply with the provisions of Article 95 (4) and (5) EC Treaty.

(7) Environmental process standards are usually based on Article 175 EC Treaty. Measures going beyond Community actions must meet the requirements of Article 176 EC Treaty.

(8) Council Directive 88/609/EEC on the limitation of emissions of certain pollutants into the air from large combustion plants.

(9) A Report by the Directorates General for: Industry; Energy; and Environment; Civil Protection and Nuclear Safety of the European Commission. s.d.

(10) P. Hall, 1998, in J. Bergmann and C. Lenz, 1998, p. 335.

(11) Quoted from the joint proposal on closer Co-operation by the German and French Foreign Ministers, Klaus Kinkel and Hervé de Charette, for the Intergovernmental Conference, published on 18 October 1996 in Bonn and Paris. Excerpts in: Internationale Politik 3/1997, p. 72ff.

(12) Hereinafter called TEC. The Treaty on European Union is called TEU in the following.

(13) European Coal and Steel Community.

(14) Economic and Monetary Union.

(15) The concept of „constructive abstention“ means that an abstention does not prevent the adoption of a decision that, on principle, has to be taken unanimously. In such a case, the decision is not binding for the abstaining Member State. This concept is an example for a flexible regulation, but it is not related to the instrument of Closer Co-operation laid down in the EU Treaty. P. Hall, in J. Bergmann, C. Lenz (ed.) 1998, p. 334.

(16) Article 43 (1) (c) TEU. 
(17) J. Ukrow, ZeuS 2/1998, p. 145.

(18) J. Janning, Integration, Vol. 4/1997, p. 287.

(19) ibid.

(20) According to Article 7 (2) of the Council's Rules of Procedure, the majority of the Member States has to vote in favour of such a decision in the Council.

(21) Unanimity, for example, is required for measures based on Article 175 (2) TEC or on Article 93 or Article 152 (4) TEC.

(22) A qualified majority is required for decisions based on Article 175 (1) and Article 95 (1) TEC.

(23) For further details, see Section 3.1.

(24) Article 43 (1) (d) TEU.

(25) The majority of Member States has to be concerned by Closer Co-operation (Article 11 (2) TEC).

(26) C.-D. Ehlermann, EuR 1997, p. 373.

(27) For example, cf. C. Thun-Hohenstein, 1995, p. 126; C.-D. Ehlermann, EuR 1997, p. 373; Wessels in M. Jopp, A. Maurer (eds.) 1998, p. 203; E. Philippart and G. Edwards, Journal of Common Market Studies, March 1999, p. 92.

(28) This becomes clear in Article 43 (1) (h) TEU where reference is made to the fact that Closer Co-operation has to comply ,with the specific additional criteria laid down in Article 11 of the Treaty establishing the European Community and Article 40 of this Treaty, depending on the area concerned, and is authorised by the Council in accordance with the procedures laid down therein".

$\underline{\text { (29) }}$ The conditions also include Article 43 (1) (c) and (d) TEU, which have already been mentioned in another context.

(30) Article 43 (1) (a) TEU.

(31) In line with the statements of the Committee on Institutional Affairs of the European Parliament in its report on the implementation of the Amsterdam Treaty of 1 July 1998; Rapporteur: Friedhelm Frischenschlager; PE 225.918/fin.

(32) V. Constantinesco, RTD eur. 1997, p.49.

(33) Article 43 (1) (b) TEU.

(34) The observance of the Community's principles and the Union's institutional framework is already laid down in other articles of the Treaties and, thus, need not be mentioned explicitly (Articles 1-16 TEC and Articles 1-7 TEU).

(35) Article 11 (1) (a) TEC. The fields with exclusive competence of the Community mainly include trade policy, general competition rules and the common organisation of agricultural markets.

(36) Article 43 (1) (e) TEU. 
(37) Primary law comprises the treaties establishing the Community, ranging from the founding treaties, the declarations and protocols adopted thereon to the amendments to the founding treaties (Unique European Act, Maastricht Treaty, Amsterdam Treaty). Secondary law is any legislation adopted on the basis of the treaties by institutions of the Community. In F. Emmert, Europarecht 1996, p. 124.

(38) V. Constantinesco, RTD eur 1997, p. 50.

(39) The same applies to measures a Member State wishes to adopt at a national level. Since environmental policy is an area of competing legislation, the Member States are basically free to adopt environmental provisions provided that there are no relevant (harmonised) Community provisions. Any national environmental regulation, however, has to live up to the provisions of (higher-ranking) primary law, in particular the EC Treaty.

(40) Moreover, the objectives differ. While national actions aim at maintaining the high protection level of one Member State, collective actions pursue objectives of Community and integration policy.

(41) See also V. Constantinesco, RTD eur 1997, p. 50.

(42) Article 11(1) (b) TEC.

(43) V. Constantinesco, RTD eur. 33(4), 1997, p. 52.

(44) A. Epiney, in K. Holzinger, P. Knöpfel, 1999, in print.

(45) Article 43 (1) (f) TEU.

(46) Article 43 (1) (g) TEU.

(47) C.-D. Ehlermann, EuR 1997, p. 374.

(48) J. Ukrow, ZeuS No. 2/1998, p. 146.

(49) The provisions include, on the one hand, the prohibition of discrimination on grounds of nationality (Article 11 (1) (c)) and, on the other hand, the obligation laid down in Article 43 (1) (f) TEU not to affect the rights and duties of the Member States not participating in Closer Co-operation.

(50) Article 11 (1) (e) TEC.

(51) ECJ, Case 178/84 (Commission vs. Germany), judgement of 12 March 1987, E 1987, 1227 , 1274.

(52) F. Emmert, 1996, p. 144.

(53) Discrimination against domestic organisations, such as the unilateral imposition of the German purity requirements for beer, is still permitted, at least according to previous jurisdiction.

(54) It is assumed that the Article 30 TEC and the mandatory requirements in the sense of the Cassis de Dijon decision of the European Court of Justice are applicable.

(55) R. Streintz, 1999, p. 243. 
(56) Article 11 (1) (e) TEC.

(57) J. Ukrow, ZEuS 2/1998, p. 148.

(58) Cf. the corresponding argumentation on Article 95 (6) TEC introducing the requirement that national measures must not affect the functioning of the internal market. S. Albin, S. Bär, NUR 4/1999, p. 185.

(59) Article 11 (2) TEC.

(60) Report of the Committee on Institutional Affairs of the European Parliament of 1 July 1998, p. 6.

(61) Together, Austria, Germany, Sweden, Finland, the Netherlands, Denmark and Luxembourg, which are often referred to as ,environmental leaders“, only have 31 votes.

(62) Article 11 (2) (2) TEC.

(63) Compared with the Luxembourg compromise, it is to be assumed that the statement of the reasons for the „veto“ against Closer Co-operation is to be taken more seriously.

(64) V. Constantinesco, RTD eur. 33(4), p. 54; P. Hall, 1998, in J. Bergmann and C. Lenz, p. 337; J. Ukrow, ZEuS 2/1998, p. 149; U. Becker, EuR 1/1998, p. 50. Unclear in this respect: J. Shaw, European Law Journal, March 1998, p. 75. Likely to disagree: C. Thun-Hohenstein, 1997, p. 120.

(65) P. Hall, 1998, in J. Bergmann and C. Lenz, p. 337.

(66) J. Ukrow, ZEuS 2/1998, p. 149.

(67) The new UK government already made it clear that these provisions give it a veto on any undesirable initiatives towards a core Europe. Prime Minister Blair in the House of Commons on 18 July 1997, Document No. 3.4. in M. Jopp, A. Mauer, O. Schmuck (eds.) 1998.

(68) G. Müller-Brandeck-Bocquet, Integration, Vol. 4/1997, p. 302.

(69) In this context, the most important fields are transport (Article 71 (1) TEC), the harmonisation of legislation (Article 95 (1) TEC), social policy in the field of vocational training and youth (Article 137 (2) TEC), but also health (Article 152 (4) TEC) and consumer protection (Article 153 (4) TEC).

(70) With the exception of waste management and measures of a general nature.

(71) The veto was also introduced in particular to reconcile the Member States that, in the Intergovernmental Conference, had pleaded in favour of making Closer Co-operation conditional on unanimous agreement in the Council. Y. Devuyst, ECSA REVIEW 3/1997, p. 12-13.

(72) Product standards include all provisions directly regulating the properties of marketable and tradable products. This applies to exhaust gas regulations for cars as well as to the ban on certain detergent additives or product-specific restrictions on the utilisation of chemical substances, e.g. PCP.

(73) Cf. Section 2.4.3. 
(74) Article 28 TEC.

(75) For national regulations, see in particular the decisions of the European Court of Justice: ECJ Case C-8/74, (Dassonville), ECR 1974, 837 and ECJ Case 120/78, (Cassis de Djion), ECR 1979, p. 649.

(76) Cf. A. Héritier, 1994, in F. v. Waarden/B. Unger.

(77) They include regulations that do not concern the product traded, but the production process, such as emission standards for factories, construction and land-use regulations and bans on the utilisation of certain chemical substances.

(78) Article 11 (1) (e) TEC.

(79) Cf. Section 2.4.3.

(80) Please note that additional duties with regard to environmental protection usually raise the costs only in the short term. In the longer term, the additional costs are, as a rule, offset by modernisation effects, renewal of the capital stock and the diversification of the product range.

(81) See also A. Epiney, 1999, p. 20, in print.

(82) Proposal for a Directive to amend Directive 88/609/EEC on the limitation of emissions of certain pollutants into the air from large combustion plants; COM(98) 415 fin. OJ C 300 of 29 September 1998.

(83) A. Epiney explicitly identifies also the field of more extensive immission protection measures as a potential application of Closer Co-operation (see above).

(84) $\operatorname{COM}(97)$ 30, OJ C 139, 6 May 1997.

(85) Greece, Portugal and Ireland also seem to take a negative view of the proposal. ENDS Daily of 16 July 1999.

(86) ENDS Daily of 13 July 1999.

(87) An opinion of the Legal Service of the Council on the legal basis of the Directive is expected to be published soon.

(88) $\operatorname{COM}(96)$ 511, OJ C 129, 25 April 1997. The question whether the introduction of a collective action would be suitable for regulations within the framework of Closer Co-operation has to remain open for the time being because a proposal to this effect has not been made at the European level as yet.

(89) Another case might be that international agreements on environmental protection specify different requirements to be met by the signatories.

(90) Entry into force in 1983.

(91) The OSPAR Convention became effective on 25 March 1998.

(92) The Convention was adopted in 1993, but has not entered into force as yet. 
(93) Without prejudice to the examination of its admissibility in international law.

(94) The following sections primarily relate to the accession of the ten Central and Eastern European candidate countries, i.e. Bulgaria, Estonia, Latvia, Lithuania, Poland, Romania, Slovak Republic, Slovenia, Czech Republic and Hungary. Many statements, however, also apply to the other countries wishing to accede. Like the CEECs listed, Cyprus already is an official candidate country. At its meeting in Helsinki in December 1999, the European Council will probably also give Malta and maybe Turkey the status of official candidate countries.

(95) Cf. A. Carius, I. von Homeyer and S. Bär, 1999.

(96) For the implementation deficit of European environmental law, see e.g. European Commission (1998), A. Jordan (1999).

(97) European Commission (1999a-e).

(98) Cf. I. von Homeyer, L. Kempmann and A. Klasing, in print.

(99) Cf. I. von Homeyer, A. Carius and S. Bär, in print.

(100) Cf. A. Jordan (1999), p. 84-85.

(101) Cf. A. Carius, I. von Homeyer and S. Bär, 1999.

(102) I. von Homeyer, A. Carius and S. Bär, 2000.

(103) Cf. Article 2 of the Protocol on the institutions with the prospect of enlargement $\left(7^{\text {th }}\right.$ Protocol of the Amsterdam Treaty).

(104) Cf. R. Dehousse, 1998, p. 147.

(105) As already highlighted no core group of permanent environmental leaders or laggards can be identified among Member States. The allocation to one or the other group varies from the issue at hand.

(106) This is due to the fact that, on account of their growing number, the laggards would have to convince relatively less ,,neutral“" Member States of their position in order to achieve a qualified majority.

(107) The successes of the pioneers would decrease due to the higher number of laggards. But, still, they would be more numerous than in a situation in which the decision-making efficiency would be considerably lower than today.

(108) Cf. A. Carius, I. von Homeyer and S. Bär, in K. Holzinger and P. Koepfel (eds.), in print.

(109) For a detailed discussion of this possibility with a view to eastern enlargement, see A. Carius, I. von Homeyer and S. Bär, 1999a.

(110) Cf. A. Epiney, 1999, in K. Holzinger and P. Koepfel (eds.).

(111) Cf. Section 2.6.

(112) Cf. Section 3.2-3.3. 
(113) This is argument is however only valid, if the higher standards of the Closer Co-operation are equally applied to the „outs“. The possibility suggested in chapters 3.2 and 3.3 not to apply the higher standards in order to avoid discrimination is at this place not taken into account.

(114) The interest in avoiding adaptation costs and the resulting competition for the position of the pace-maker in the Community already has been an important motor of European environmental policy to date. Cf. A. Heritier, 1994.

(115) Cf. K. D. Ehlermann, 1997, p. 379.

C 2000 by Bär et al.

formated and tagged by MN, 10.10.2000 